Jurnal Media Analis Kesehatan, Vol. 8, No.2, November 2017

http://journal.poltekkes-mks.ac.id/ojs2/index.php/mediaanalis

e-ISSN : 2621-9557

p-ISSN : 2087-1333

\title{
PENGARUH KADAR RHEUMATOID FACTORS TERHADAP KADAR C- REAKTIF PROTEIN DAN NILAI LAJU ENDAP DARAH PADA PENDERITA ARTRITIS REUMATOID
}

\author{
Syamsul Bakhri \\ Jurusan Analis Kesehatan Poltekkes Kemenkes Makassar \\ Koresponden : Syamsulbakhri0909@gmail.com
}

\begin{abstract}
ABSTRAK
Penelitian ini dilatarbelakangi penelitian sebelumnya yang menyatakan bahwa 20$30 \%$ penderita AR menunjukkan seronegatif untuk RF. Keadaan ini tentu dapat menghambat proses pengobatan pada penderita. Untuk itu perlu adanya pemeriksaan penunjang terkait penyakit Artritis Reumatoid, yakni pemeriksaan kadar CRP dan nilai LED.Tujuan penelitian untuk mengetahui dan menentukanpengaruh kadar RF terhadap kadar CRP dan nilai LED pada penderita Artritis Reumatoid. Penelitian ini termasuk jenis penelitian observasi analitik melalui pendekatan studi regresi dengan teknik pengambilan sampel menggunakan purposive sampling, dengan sampel yang diperiksa sebanyak 12 orang. Subyek penelitian ini adalah penderita Artritis Reumatoid yang telah memenuhi kriteria inklusi dan eksklusi yang berada di daerah Limbung, Kab. Gowa. Pada subyek, diperiksa kadar RF, CRP, dan LED nya.Dari hasil penelitian, 8 subyek yang masuk sebagai kriteria AR, diteliti menunjukkan seronegatif untuk RF. Sehingga RF tidak dapat dijadikan standar dalam penegakan diagnosa AR. Adapun untuk CRP dan LED tidak dapat dilihat pengaruhnya terhadap RF karena data yang diperoleh tidak berdistribusi normal. Namun nilai LED masih dapat digunakan sebab menunjukkan peningkatan yang signifikan terhadap gejala AR.
\end{abstract}

Kata Kunci : Rheumatoid Factors, C-Reaktif Protein, Laju Endap Darah.

\section{PENDAHULUAN}

Artritis Reumatoid (AR) adalah suatu penyakit inflamasi sistemik kronik yang berdampak pada beberapa jaringan dan organ seperti kulit, pembuluh darah, jantung, hati, paru-paru, otot, dan terutama menyerang sendi. Jika menyerang sendi, AR menyebabkan peradangan sendi nonsupuratif sampai kerusakan kartilago artikular. (Umar B, 2016)

Penyakit AR menyerang individu di seluruh dunia dari berbagai suku bangsa. Sekitar $1 \%$ orang dewasa menderita reumatoid artritis yang jelas, dan dilaporkan bahwa di Amerika Serikat setiap tahun timbul kira-kira 750 kasus baru per satu juta penduduk. (Price S.A dan Wilson L.M, 2014)

Penyebab AR belum diketahui dengan pasti. Ada yang mengatakan karena mikoplasma, virus, dan sebagainya. Namun, semuanya belum terbukti. Autoantibodi diyakini memiliki peranan dalam aktivitas patogenetik penyakit AR. 
Jurnal Media Analis Kesehatan, Vol. 8, No.2, November 2017

http://journal.poltekkes-mks.ac.id/ojs2/index.php/mediaanalis

e-ISSN : 2621-9557

p-ISSN : 2087-1333

(Perhimpunan

Indonesia, 2014)

Pada penderita AR, terjadi peningkatan kadar molekul kostimulatoris yang menimbulkan respon imun CD4 Th2 sehingga menghasilkan autoantibodi, yaitu anti IgG atau rheumatoid factor (RF). (Handojo I, 2004)

Rheumatoid factor (RF) merupakan suatu kelompok autoantibodi spesifik yang dapat mengikat antibodi lain. RF dapat berupa variasi $\mathrm{IgG}, \operatorname{IgM}$, atau $\mathrm{IgA}$, tetapi diduga IgM berperan penting, yang bereaksi dengan IgG sebagai antigen. Kompleks imun RF ini dapat memperberat proses inflamasi dan mempengaruhi komplemen. $\mathrm{RF}$ merupakan pertanda khas AR, dapat ditemukan pada $80 \%$ pasien dengan AR. (Umar B, 2016).

\section{C-Reaktif Protein (CRP)} merupakan salah satu Protein Fase Akut (PFA), termasuk golongan protein yang kadarnya dalam darah meningkat pada infeksi akut sebagai respons imunitas nonspesifik. (Baratawidjaja K.G. dan Rengganis I, 2012). Dalam waktu yang relatif singkat (6-8 jam) setelah terjadinya reaksi radang akut/kerusakan jaringan, sintesis dan sekresi CRP meningkat dengan tajam. (Handojo I, 2004)

Laju Endap Darah (LED) adalah kecepatan eritsosit (dalam darah yang diberi antikoagulan) yang jatuh ke dasar sebuah kolom vertikal dalam waktu tertentu. (Ronald A.S dan Richard A.M, 2004). Kecepatan pengendapan ditentukan oleh interaksi dua gaya fisika yang berlawanan, yaitu tekanan ke bawah akibat gravitasi bumi dan tekanan ke atas akibat perpindahan plasma. (Umar B, 2016).

LED meningkat pada penyakit inflamasi aktif seperti artritis reumatoid (AR), infeksi kronis, penyakit kolagen, dan neoplastik. (Kiswari R, 2010).

Dalam jurnal internasional yang berjudul Long-term outcomes of destructive seronegative (rheumatoid) arthritis description of four clinical cases (Nikiphorou dkk, 2016), bahwa hingga $20-30 \%$ pasien yang termasukgejala artritis reumatoid, dalam uji klinis menunjukkan seronegatif. PadaRumah sakit Yayasan Rematik "Finlandia Heinola", dalam mendiagnosis gejala awal artritis reumatoid, (selama lebih kurang 25 tahun) hanya menindaklanjuti pasien yang seropositif, karena reumatologis meyakini bahwa penyakit seropositif (RF positif pada waktu itu) adalah satu-satunya presentasi yang benar dari penyakit ini.

Pengukuran CRP atau LED merupakan kunci untuk pemantauan penyakit AR. Pemantauan ini perlu untuk meningkatkan pengobatan agar penyakit lebih terkendali atau secara hati-hati menurunkan dosis obat jika pasien telah terkontrol dan selanjutnya secara terus-menerus. (Perhimpunan Reumatologi Indonesia, 2014)

Berdasarkan penjelasan tersebut, kadar CRP dan nilai LED berkaitan dengan proses peradangan dan infeksi pada pasien AR. Penentuan kadar RF saja tentu belum cukup untuk mendiagnosis AR. Karena telah dijelaskan bahwa, 20-30\% penderita ARmenunjukkan seronegatif untukRF. Keadaan ini tentu dapat menghambat proses pengobatan pada 
Jurnal Media Analis Kesehatan, Vol. 8, No.2, November 2017

http://journal.poltekkes-mks.ac.id/ojs2/index.php/mediaanalis

e-ISSN : 2621-9557

p-ISSN : 2087-1333

si penderita. Untuk itu perlu adanya pemeriksaan penunjang terkait penyakit artritis reumatoid, yaitu pemeriksaan kadar CRPdan nilai LED.

Berdasarkan penelitian sebelumnya (Nurul Hudayah, 2016), bahwa di daerah Limbung, kabupaten Gowa, Sulawesi selatan, dari 30 tersangka penderita AR yang diperiksa, terdapat 10 orang yang positif menderita AR.

Bertitik tolak dari landasan di atas, peneliti bermaksud untuk melakukan studi terkait Pengaruh KadarRheumatoid Factor (RF) terhadap Kadar C-Reaktif Protein (CRP) dan Nilai Laju Endap Darah (LED) pada penderita Artritis Reumatoid (AR). Ddapun tujuan penelitian adalah untuk mengetahui pengaruhkadar rf terhadap kadar crp dan nilai led pada penderita artritis reumatoid.

\section{METODE}

\section{Jenis Penelitian, Lokasi dan waktu penelitian}

Penelitian ini termasuk jenis penelitian observasi analitik dengan pendekatan studi regresi, untuk mengetahui keberadaan hubungan dan tingkat hubungan antar variabel yang direfleksikan dalam koefisien regresi. Sehingga hasilnya dapat digeneralisasikan ke populasi. Lokasi penelitian dilaksanakan di Laboratorium Imunoserologi Jurusan Analis Kesehatan, Poltekkes Kemenkes Makassar. pada bulan Februari - April 2017.

Populasi, Sampel dan Teknik pengambilan sampel, alat dan bahan

Populasi pada penelitian ini adalah penderita AR yang memenuhi krtiteria inklusi dan eksklusi di Kel. Limbung, Kab. Gowa. Sampel pada penelitian ini adalah 12 penderita AR yang memenuhi kriteria. Kriteria inklusi dalam penelitian ini yaitu, penderita bersedia menjadi subjek penelitian dengan syarat mengisi lembar persetujuan (informed concert).

Teknik pengambilan sampel penelitian ini menggunakan teknik Purposive Sampling. Bahan penelitian yang digunakan yaitu; serum, whole blood, reagen lateks (RF dan CRP), kontrol positif, dan kontrol negatif, Glysin Buffer Solution (GBS). Instrumen penelitian yang digunakan yaitu; vaccutainer (clot activator dan $\left.\mathrm{K}_{2} \mathrm{EDA}\right)$, holder, kapas alkohol, stuing, masker, dan handscoon, mikropipet 50 ul, tip kuning, pipet tetes, papan slide, pipet westergreen, dan standar LED.

\section{Cara Pengumpulan Data dan Prosedur Penelitian Pra analitik}

Tahap pra analitik dalam penelitian ini yaitu disiapkan alat dan bahan untuk pengambilan sampel darah dan serum, dilakukan sampling pada pasien (1 pasien untuk 2 tabung), tabung bertutup merah (tanpa antikoagulan) untuk pemeriksaan $\mathrm{RF}$ dan CRP, tabung bertutup ungu ( $\mathrm{K}_{2}$ EDTA) untuk pemeriksaan LED. Perolehan serum pada tabung bertutup merah dengan cara didiamkan selama 1 jam, kemudian disentrifuge dengan kecepatan 2500 rpm selama 10 menit.

\section{Analitik}

Pemeriksaan kadar RF (metode aglutinasi lateks)

Prinsip : HumaTex RF berdasarkan reaksi aglutinasi antara Rheumatoid Factors (RF) dari spesimen pasien 
Jurnal Media Analis Kesehatan, Vol. 8, No.2, November 2017

http://journal.poltekkes-mks.ac.id/ojs2/index.php/mediaanalis

e-ISSN : 2621-9557

p-ISSN : 2087-1333

atau serum kontrol dengan human imunoglobulin $\mathrm{G}$ ( $\mathrm{IgG}$ ) yang dilapisi dalam partikel latex polistiren. Reaksi positif ditandai dengan aglutinasi yang terbentuk.

Komposisi reagen

LR: Suspensi mengandung partikel latex polistiren berwarna putih yang dilapisi dengan human imunoglobulin $\mathrm{G}(\mathrm{IgG})$

$\mathrm{PC} \quad: 1.0 \mathrm{ml}$ Control Serum Positif (tutup merah) Siap digunakan. Dibuat dari Anti-Human IgG (Goat)

NC : $1.0 \mathrm{ml}$ Control Serum Negatif (tutup hijau) Siap digunakan, non-reaktif dengan LR.

GBS : $100 \mathrm{ml}$ Glycine $\mathrm{NaCl}$ Buffer Glycine dan NaCL

LR, PC, NC, dan GBS mengandung Sodium Azida 0.095\%

Langkah kerja (kualitatif)

Pertama-tama disiapkan alat dan bahan di atas meja kerja. KIT reagen dan sampel dibiarkan sampai mencapai suhu ruang. Sebelum digunakan, reagen dihomogenkan dahulu. Kemudian dipipet sebanyak 1 tetes kontrol ke atas lingkaran slide dan ditambahkan reagen latex sebanyak 1 tetes, dihomogenkan. Jika hasil sesuai, maka dilanjutkan pada pemeriksaan sampel. Sampel dipipet sebanyak 40 ul dan ditambahkan reagen latex sebanyak 1 tetes dan disebar sampai tanda batas lingkaran slide. Setelah itu, dirotator secara manual kecepatan $\pm 100 \mathrm{rpm}$ selama 2 menit. Hasil kemudian dibaca oleh 2 orang atau lebih untuk konfirmasi. Jika hasil positif dilanjutkan ke pemeriksaan semi-kuantitatif.

Interpretasi hasil: aglutinasi yang tampak menunjukkan RF yang terkandung lebih dari (> $12 \mathrm{IU} \mathrm{mL}$ ).

\section{Pemeriksaan kadar CRP (metode aglutinasi lateks).}

Prinsip

CRP lateks test adalah tes cepat metode

aglutinasi slide untuk kualitatif dan semi-kuantitatif untuk mendeteksi CReaktif Protein dalam serum. Reagen CRP mengandung partikel yang dilapisi dengan antibodi antihumanCRP yang spesifik sehingga akan terjadi reaksi aglutinasi jika bereaksi dengan CRP dalam serum pasien.

Komposisi reagen

CRP latex: Suspensi mengandung partikel latex berwarna putih yang dilapisi dengan antibodi anti-human C-Reaktif Protein yang spesifik. Sensitivitas deteksi yaitu $6 \mathrm{mg} / \mathrm{L}$ $250 \mathrm{mg} / \mathrm{L}$. Sodium Azide $0.95 \mathrm{~g} / \mathrm{L}$.

Kontrol Positif : Human Serum, Sodium Azide 0.95 g/L. Kontrol Negatif : Animal Serum, Sodium Azide $0.95 \mathrm{~g} / \mathrm{L}$.

Langkah kerja (kualitatif)

Pertama-tama disiapkan alat dan bahan di atas meja kerja. KIT reagen dan sampel dibiarkan sampai mencapai suhu ruang. Sebelum digunakan, reagen dihomogenkan terlebih dahulu. Kemudian dipipet sebanyak 1 tetes kontrol ke atas lingkaran slide dan ditambahkan reagen latex sebanyak 1 tetes, dihomogenkan. Jika hasil sesuai, maka dilanjutkan pada pemeriksaan sampel. Sampel dipipet sebanyak 50 ul dan ditambahkan reagen latex sebanyak 1 tetes, dihomogenkan dan disebar sampai tanda batas lingkaran slide. Setelah itu, dirotator secara manual degan kecepatan $\pm 100 \mathrm{rpm}$ selama 2 menit. Hasil kemudian dibaca oleh 2 orang atau lebih sebagai konfirmasi hasil. Jika hasil positif 
Jurnal Media Analis Kesehatan, Vol. 8, No.2, November 2017

http://journal.poltekkes-mks.ac.id/ojs2/index.php/mediaanalis

e-ISSN : 2621-9557

p-ISSN : 2087-1333

dilanjutkan pada pemeriksaan semikuantitatif.

Interretasi hasil : aglutinasi yang tampak menunjukkan CRP yang terkandung sama dengan atau lebih dari $6 \mathrm{mg} / \mathrm{l}$ dalam serum spesimen yang tidak diencerkan.

Langkah kerja (semi-kuantitatif).

Pertama-tama diteteskan larutan salin sebanyak 50 ul pada slide 2, 3, 4, dan 5. Kemudian ditambahkan 50 ul serum pasien pada slide 1 dan 2, dihomogenkan. Dipipet 50 ul dari slide 2 ke slide 3 yang berisi larutan salin, dilakukan hal yang sama sampai slide terakhir, pada slide terakhir dibuang sebanyak $50 \mathrm{ul}$. Dengan menggunakan pipet, sampel diluen kemudian dihomogenkan dan disebar sampai batas slide mulai dari slide 5 sampai slide 2. Setelah itu, ditambahkan dengan reagen latex dan diamati aglutinasi yang terbentuk.

Interpretasi hasil : aglutinasiyang tampak pada pengenceran tertentu dikalikan dengan sensitivitas alat menunjukkan titer CRP.

Pemeriksaan nilai LED (metode westergreen)

Prinsip: Darah yang telah ditambahkan antikoagulan ditemptkan dalam tabung panjang berskala 0-200 $\mathrm{mm}$, bila didiamkan pada suhu kamar dalam waktu tertentu maka eritrosit akan turun ke dasar tabung berdasarkan perbedaan berat jenis antara eitrosit dan plasma. Tinggi lapisan plasma sampai tepat di atas pembatasan eritrosit yang paling padat dilaporkan sebagai laju endap darah.

Langkah kerja: Disiapkan peralatan dan bahan di atas meja kerja, kemudian dimasukkan dalam tabung reaksi $250 \mu l \quad \mathrm{NaCl} \quad 0,9 \%$ dan ditambahkan $1000 \quad \mu l$ darah kemudian homogenkan (perbandingan1 bagian $\mathrm{NaCl}$ dan 4 bagian darah). Setelah itu, pipet westergren dimasukkan ke dalam tabung dengan menggunakan pom karet. Isap darah hingga tanda 0 lalu pasang pipet di atas rak Westergreen. Pipet kemudian dibiarkan selama 60 menit pada suhu kamar dan dibacaketinggian plasma terhadap endapan eritrosit. Dicatat hasilnya dan dilaporkan dalam $\mathrm{mm} / \mathrm{jam}$.

Interpretasi hasil :nilai yang menunjukkan lebih dari $15 \mathrm{~mm} / \mathrm{jam}$ (untuk pria) dan $20 \mathrm{~mm} / \mathrm{jam}$ (untuk wanita), mengindikasikan adanya peradangan.

Analisis Data

$\begin{array}{ccr}\text { Data } & \text { ditentukan } & \text { distribusi } \\ \text { normalitasnya } & \text { terlebih } & \text { dahulu } \\ \text { menggunakan } & \text { uji } & \text { Saphiro- }\end{array}$ Wilkdengan syarat nilai probabilitas lebih dari 0.05 ( $p>0.05$ ). Setelah itu, data dianalisis secara regretif, untuk melihat hubungandan tingkat hubungan kadar RF terhadap kadar CRP dan nilai LED menggunakan aplikasi pengolah data Statistical Package for the Social Sciences24(SPSS24).

\section{HASIL}

Subyek pada penelitian ini adalah sebanyak 12 orang, yang masuk kriteria sebagai penderita Artritis Reumatoid dan dijadikan sampel sebanyak 8 orang. Sebelum dilakukan pengambilan darah, subjek diberi penjelasan mengenai maksud dan tujuan pemeriksaan serta diwajibkan mengisi kuisioner untuk memudahkan peneliti dan formulir pesetujuan sebagai tanda penerimaan subjek. 
Jurnal Media Analis Kesehatan, Vol. 8, No.2, November 2017

http://journal.poltekkes-mks.ac.id/ojs2/index.php/mediaanalis

e-ISSN : 2621-9557

p-ISSN : 2087-1333

Berdasarkan pemeriksaan 12 sampel darah vena dari 12 subyek penelitian, diperoleh hasil sebagai berikut :

Tabel 1.

Hasil Kadar RF, Kadar CRPdan Nilai LED pada suspek Artritis Reumatoid

\begin{tabular}{|c|c|c|c|c|c|}
\hline \multirow[t]{2}{*}{ No } & \multirow{2}{*}{$\begin{array}{c}\text { Kode } \\
\text { Sampel }\end{array}$} & \multicolumn{3}{|c|}{ Hasil Pemeriksaan } & \multirow{2}{*}{$\begin{array}{c}\text { Kesesuaian } \\
\text { Kriteria } \\
\text { ACR/EULAR }\end{array}$} \\
\hline & & $\begin{array}{c}\mathbf{R F} \\
(\mathbf{I U} / \mathbf{m l})\end{array}$ & $\begin{array}{c}\text { CRP } \\
(\mathrm{mg} / \mathrm{L})\end{array}$ & $\begin{array}{c}\text { LED } \\
\text { (mm/jam) }\end{array}$ & \\
\hline 1 & 1 & Negatif (-) & Negatif (-) & 8 & $\mathrm{Ya}$ \\
\hline 2 & 2 & Negatif (-) & Negatif (-) & 24 & Tidak \\
\hline 3 & 3 & Negatif (-) & Negatif (-) & 12 & $\mathrm{Ya}$ \\
\hline 4 & 4 & Negatif (-) & Negatif (-) & 18 & $\mathrm{Ya}$ \\
\hline 5 & 5 & Negatif (-) & Negatif (-) & 18 & $\mathrm{Ya}$ \\
\hline 6 & 6 & Negatif (-) & $\begin{array}{c}\text { Positif }(+)= \\
6\end{array}$ & 125 & $\mathrm{Ya}$ \\
\hline 7 & 7 & Negatif (-) & Negatif (-) & 33 & $\mathrm{Ya}$ \\
\hline 8 & 8 & Negatif (-) & Negatif (-) & 54 & Tidak \\
\hline 9 & 9 & Negatif (-) & Negatif (-) & 26 & $\mathrm{Ya}$ \\
\hline 10 & 10 & Negatif (-) & Negatif (-) & 27 & Tidak \\
\hline 11 & 11 & Negatif (-) & Negatif (-) & 35 & Tidak \\
\hline 12 & 12 & Negatif (-) & Negatif (-) & 47 & $\mathrm{Ya}$ \\
\hline
\end{tabular}

Sumber : Data Primer 2017

Pada tabel 1. di atas didapatkan bahwa dari 12 orang yang dijadikan subjek, hanya 8 orang yang memenuhi kriteria sebagai sampel. Dari ke-8 sampel tersebut, semuanya menunjukkan kadar RF yangnegatif dan hanya satu yang menunjukkan hasil positif pada kadar CRP dengan titer $6 \mathrm{mg} / \mathrm{L}$. Lebih jelasnya dapat dilihat pada table 2 . berikut ini :

Tabel 2.

Hasil Kadar RF, Kadar CRP dan Nilai LED pada penderita Artritis Reumatoid

\begin{tabular}{|c|c|c|c|c|c|}
\hline \multirow[t]{2}{*}{ No } & \multirow{2}{*}{$\begin{array}{c}\text { Kode } \\
\text { Sampel }\end{array}$} & \multicolumn{3}{|c|}{ Hasil Pemeriksaan } & \multirow{2}{*}{$\begin{array}{c}\text { Kesesuaian } \\
\text { Kriteria } \\
\text { (ACR/EULAR) }\end{array}$} \\
\hline & & $\begin{array}{c}\text { RF } \\
(\mathbf{I U} / \mathbf{m l})\end{array}$ & $\begin{array}{c}\text { CRP } \\
(\mathrm{mg} / \mathrm{L})\end{array}$ & $\begin{array}{c}\text { LED } \\
(\mathbf{m m} / \mathbf{j a m})\end{array}$ & \\
\hline 1 & 1 & Negatif (-) & Negatif (-) & 8 & $\mathrm{Ya}$ \\
\hline 2 & 3 & Negatif (-) & Negatif (-) & 12 & $\mathrm{Ya}$ \\
\hline 3 & 4 & Negatif (-) & Negatif (-) & 18 & $\mathrm{Ya}$ \\
\hline 4 & 5 & Negatif (-) & Negatif (-) & 18 & $\mathrm{Ya}$ \\
\hline 5 & 6 & Negatif (-) & Positif $(+)=6$ & 125 & $\mathrm{Ya}$ \\
\hline 6 & 7 & Negatif (-) & Negatif (-) & 33 & $\mathrm{Ya}$ \\
\hline 7 & 9 & Negatif (-) & Negatif (-) & 26 & $\mathrm{Ya}$ \\
\hline 8 & 12 & $\begin{array}{l}\text { Negatif (-) } \\
\text { Mean }\end{array}$ & Negatif (-) & $\begin{array}{c}47 \\
35.875\end{array}$ & $\mathrm{Ya}$ \\
\hline
\end{tabular}


Jurnal Media Analis Kesehatan, Vol. 8, No.2, November 2017

http://journal.poltekkes-mks.ac.id/ojs2/index.php/mediaanalis

e-ISSN : 2621-9557

p-ISSN : 2087-1333

Data yang telah diperoleh kemudiandilanjutkan dengan uji normalitas (Shapiro-Wilk)dengan syarat nilai probabilitas lebih dari $0.05(p>0.05)$ seperti terlihat pada tabel di bawah ini :

Tabel 3. Hasil Uji Normalitas RF terhadap CRP

\begin{tabular}{cccccccc}
\hline \multicolumn{1}{c}{ Tests of Normality } \\
\hline & RF & \multicolumn{3}{c}{ Kolmogorov-Smirnov ${ }^{\mathrm{a}}$} & \multicolumn{3}{c}{ Shapiro-Wilk } \\
& \multicolumn{1}{c}{ Statistic } & df & Sig. & Statistic & df & Sig. \\
CRP & 0 & .513 & 8 & .000 & .418 & 8 & $\mathbf{. 0 0 0}$ \\
a. Lilliefors Significance Correction & & & & \\
\hline
\end{tabular}

Berdasarkan output di atas, diketahui bahwa nilai signifikansi yaitusebesar 0.000 lebih kecil dari 0.05 sehingga dapat disimpulkan bahwa data yang diuji tidak berdistribusi normal karena terdapat satu nilai ekstrim pada kadar CRP yakni $6 \mathrm{mg} / \mathrm{L}$ sehingga data tidak bisa dilanjutkan pada uji regresi.

Koresponden

\begin{tabular}{|c|c|c|c|c|c|c|c|}
\hline \multicolumn{8}{|c|}{ Tests of Normality } \\
\hline & \multirow[t]{2}{*}{$\mathbf{R F}$} & \multicolumn{3}{|c|}{ Kolmogorov-Smirnova } & \multicolumn{3}{|c|}{ Shapiro-Wilk } \\
\hline & & Statistic & Df & Sig. & Statistic & $\mathrm{df}$ & Sig. \\
\hline LED & 0 & .280 & 8 & .064 & .710 & 8 & .003 \\
\hline
\end{tabular}

Berdasarkan output di atas, diketahui bahwa nilai signifikansi yaitu sebesar 0.003 lebih kecil dari 0.05 sehingga dapat disimpulkan bahwa data yang diuji tidak berdistribusi normal karena terdapat satu nilai ekstrim pada nilai LED yakni $125 \mathrm{~mm} / \mathrm{jam}$ sehingga data tidak bisa dilanjutkan pada uji regresi.

Nilai rata-rata LED menunjukkan peningkatan yang signifikan.

\section{KESIMPULAN}

Berdasarkan hasil penelitian yang telah dilakukan, dapat disimpulkan bahwa dari semua pasien yang telah diteliti yang mempunyai gejala AR, masih menunjukkan hasil RF dan CRP yang negatif. Ini berarti paramater RF dan CRP metode kualitatif sudah tidak bisa dijadikan standar dalam penetapan diagnosa penyakit AR. Sedangkan nilai LED masih dapat digunakan sebab menunjukkan peningkatan yang signifikan terhadap gejala AR. Adapun pengaruh RF terhadap CRP dan LED tidak dapat diinterpretasikan karena data yang diperoleh tidak berdistribusi normal.

\section{SARAN}

Karena keterbatasan peneliti dalam menentukan metode yang akurat, maka disarankan peneliti selanjunya agar menggunakan metode yang lebih spesifik dan sensitif. Disarankan pula untuk mencoba reagen yang menggunakan 
Jurnal Media Analis Kesehatan, Vol. 8, No.2, November 2017

http://journal.poltekkes-mks.ac.id/ojs2/index.php/mediaanalis

e-ISSN : 2621-9557

p-ISSN : 2087-1333

human Imunoglobulin $\mathrm{M} \quad(\mathrm{IgM})$ dalam partikel lateks.

\section{DAFTAR PUSTAKA}

Alberthina dan Siswanto, 2010. Pengukuran Presipitasi dengan Light

Scattering/Nefletometri. http://www.slideshare.net/ andreei/ti68332789.

Diakses tanggal 8 Januari 2017

Handojo I, 2004. Imunoasai Terapan pada Beberapa Penyakit Infeksi. Cetakan I. Surabaya : Airlangga University Press

Hudayah N, 2015. Analisis Kadar Hemoglobin dan Nilai Laju Endap Darah pada penderita Artritis Reumatoid. Poltekkes : Makassar

Kresno S.B, 2010. Diagnosis dan Prosedur Laboratorium Imunologi. Jakarta : FKUI

Kumar V, Cotran R.S, dan Robbins S.B, 2007. Buku Ajar Patologi. Edisi 7. Vol 2. Jakarta : EGC

Medical Lab, 2015.

Autoagglutination vs

Rouleaux.

http://www.medical-

labs.net/autoagglutination-vsrouleaux-formation-2605/.

Diakses tanggal 3 Januari 2017

Nugraha J, 2015. Pengantar Dasardasar Imunoasai.

http://www.slide

share.net/jusaknugraha/penga ntar-imunoasai. Diakses tanggal 4 Januari 2017

Perhimpunan Rheumatologi Indonesia, 2014. Diagnosis dan Pengelolaan Rheumatoid Artritis. Jakarta : FKUI.
Www.reumatologi.or.id/reure

$\mathrm{k} /$ download/23. Diakses 22 November 2016

Price S.A dan Wilson L.M, 2014. Konsep Klinis Proses-proses Penyakit. Edisi 6. Vol 2. Jakarta : EGC

Rianiari U, 2014. Gambaran Pengobatan dan Kualitas Hidup pada Pasien Rheumatoid Arthritis di Instalasi Rawat Jalan RS PKU Muhammadiyah Yogyakarta. Yogyakarta : Universitas Gadjah Mada. http://etd.repository.ugm.ac.i

d. Diakses tanggal 23 November 2016

Riskiyatul A, 2013. Reumatoid Artritis Lansia. https://www.academia.edu 17579877/REUMATOID_AR TRITIS--

LANSIA? auto=download.

Diakses tanggal 4 Desember 2016

Ronald A.S dan Richard A.M, 2004. Tinjauan Klinis Hasil Pemeriksaan Laboratorium. Edisi 11. Jakarta : EGC

Setiawanaa, 2013. Artritis Reumatoid pada Hewan. https://judgelodogy.wordpres s.com/2013/08/23/rheumatoid arthritis/. Diakses tanggal 8 Januari 2017

Umar B, 2016. Penuntun Praktik Klinik Laboratorium Kesehatan. Makassar 